Litigation

\section{Why tobacco litigation?}

\section{R Daynard}

\section{Just how important is litigation in achieving the goals of the tobacco control community?}

W hen a Los Angeles jury recently
assessed $\$ 28$ billion in punitive damages against Philip Morris in Bullock $v$ Philip Morris Companies the tobacco control community cheered The jury had calculated that only one in 28000 Californians who have suffered from tobacco caused disease ever sues, so to make Philip Morris confront the real cost of its misbehaviour, they multiplied a typical \$1 million compensatory damage award (for medical bills, lost wages, and pain and suffering) by 28000 . Right on! Even though the trial judge subsequently reduced the award to $\$ 28$ million $^{2}$ that is still enough to encourage many more suits to be filed.

Why ask "why tobacco litigation?" The reason is that the tobacco control community may soon have to decide just how important litigation is to achieving our goals. Two current examples put the issue nicely. First, the recently certified "Simon II" punitive damage class action $^{3}$ would strip the punitive damages claims from all cases that may be brought against tobacco companies by Americans who have become ill from their products, and allow these instead to be decided by a single jury verdict or settlement. Although in theory plaintiffs would still be able to recover compensatory damages in individual actions (medical expenses, lost income, pain and suffering, and so on), in practice they may not be able to find lawyers willing to take their case on contingency fee where punitive damages are off the table.

Thus while this procedure, if upheld on appeal, may offer financial benefits for tobacco victims and the tobacco control community, it may also effectively quash tobacco litigation in America. Furthermore, a possible jury decision finding the tobacco companies owe little or no punitive damages would be binding on all individual plaintiffs. What position should we take on this? Disagreement about the merits of a similar tradeoff in the "Global Settlement" of 1997 led to civil war within the community. ${ }^{45}$ Second, the Framework Convention on Tobacco Control may contain provisions that could carry the possibility of viable tobacco litigation from the USA to the entire world. How hard should we press for these provisions, and what steps

should we take to implement them if they are adopted?

\section{ACHIEVEMENTS SO FAR}

What then has litigation achieved for tobacco control? First, the millions of documents obtained in the state Medicaid litigation and subsequent cases, now stored in paper depositories in Minnesota in the USA and in Guildford in the UK and available online through various sources, have revolutionised tobacco control research and advocacy. Before the documents we could often infer tobacco industry intent: now we can demonstrate it. The documents reveal an amazing variety and geographical range of tobacco industry misconduct, including targeting children, deliberately misleading scientists, politicians, and customers about the lethality and addictiveness of their products, and conspiring with smugglers and money launderers around the world. ${ }^{6}$ Whether in the courtroom, the media, or the legislature, the industry can no longer succeed in portraying itself as the innocent supplier of a product independently demanded by its hedonistic clientele.

\begin{abstract}
When juries repeatedly award punitive damages in the millions or billions of dollars, talk show hosts, legislators, and even industry executives get the message that this industry is no longer being regarded as a law abiding member of the community
\end{abstract}

Second, large verdicts in tobacco cases made possible by the documents have added to the industry's confusion and loss of legitimacy. When juries repeatedly award punitive damages in the millions or billions of dollars, talk show hosts, legislators, and even industry executives get the message that this industry is no longer being regarded as a law abiding member of the community. The increasing possibility of bankruptcy further weakens the industry's position politically and in the financial community.

Third, one result of the industry's flailing about to find a way of defending these cases has been the first stirrings of responsible behaviour on their part. Not only is Philip Morris now conceding on its website that cigarette smoking is addictive and causes lung cancer and other diseases, ${ }^{7}$ but under the pressure of individual and class action cases attacking the "light cigarette" scam, it is for a limited time placing a brochure under the cellophane on packs of "light" cigarettes stating that there is no such thing as a safe cigarette. ${ }^{8}$ Of course, if they really wanted to behave responsibly they would make the brochures permanent, or better yet, stop using deceptive terms such as "light" altogether.

Fourth, the settlements of the state Medicaid cases have added about $\$ 10$ billion a year to the industry's costs, forcing substantial price increases that have contributed to dramatic declines in US smoking rates. The substantial cost of defending the lawsuits has also been added to the price of cigarettes. The publicity about industry stratagems to recruit teenage smokers has also probably contributed to record declines in smoking among minors ${ }^{9}$ who do not appreciate being manipulated. Paradoxically, even the talk show discussions about how "unreasonable" it is for a smoker to sue when she contracts lung cancer serve to reduce consumption by reminding listeners how unreasonably dangerous it is to smoke.

Fifth, while only a small proportion of the money received from the state Medicaid settlements has been spent as promised on tobacco control programmes, that is nonetheless much more than had been spent previously.

Sixth, tobacco litigation, which 10 years ago was considered quixotic and hopeless, is now serving as a paradigm for lawsuits against manufacturers of handguns, lead paint, fast foods, and other products which have been designed or marketed irresponsibly.

Seventh, and finally, "public interest" litigation brought by non-governmental organisations (NGOs) in India and Uganda have produced judicial orders requiring that public places be smokefree, while such litigation in Bangladesh and Mali have resulted in injunctions against illegal tobacco industry marketing practices. ${ }^{10} 11$

\section{FUTURE POTENTIAL}

While these accomplishments have obviously been extremely important, what can be expected from additional litigation? Are most of the potential benefits behind us? There are several reasons for believing that the best is yet to come.

First, unlike legislation and administrative regulation, litigation operates retrospectively, asking the question whether the corporate decisions that contributed to the plaintiff's illness were reasonable or unreasonable, in good 
faith or fraudulent. While a tobacco executive who only has to worry about legislation and regulations can target children, deny smoking causes disease, or pretend that "light" cigarettes are safer than ordinary ones, all without worrying about legal sanctions, the possibility of civil remedies makes all these activities problematic. Instead of relying on loopholes, the executive must ask himself how an angry jury five or 20 years hence will regard his conduct. The threat of legal liability has improved the design and marketing of other products: it may yet do the same for cigarettes.

Further, there are many areas of tobacco company misbehaviour that are only beginning to be explored. The "light" cigarette scam, smuggling and money laundering, ingredients that increase addictiveness or mask toxicity, and the companies' ability to make less toxic or incendiary cigarettes that would be acceptable to smokers, are all areas where suggestive documents are now available but where focused discovery in cases raising these specific issues might well produce a wealth of detailed information. Cases that explore new areas also open new fronts in the public critique of industry behaviour. In addition, if past is prologue there are probably large areas of misconduct that have not yet been discovered.

Tobacco litigation is still relatively rare outside the USA. Of approximately 1600 lawsuits pending against Philip Morris as of 30 September 2002, only 83 were not in American courts. ${ }^{12}$ Thus, the rest of the world has barely begun to experience the benefits that flow from tobacco litigation. For example, although the same companies that have been discredited in the USA also dominate most other markets, "tobacco executive" does not yet bear the connotations of "inveterate liar" and "mass killer" in other countries. The process of knocking these pillars of the established order off their pedestals, as practised in the USA, requires an escalating barrage of revelations of misconduct. While documents such as those detailing Operation Berkshire, where the tobacco industry decided to take its successful American conspiracy worldwide, ${ }^{13}$ are relevant in many countries and are available on the internet, they have not generally received wide publicity in the target countries. Lawsuits in each country which make use of these documents, and perhaps uncover new ones, could be very useful and may even be necessary in order to focus the attention of the press and public on the malign behaviour and intentions of the local companies and their transnational parents.

There are other benefits to public health from tobacco litigation in a particular country which also accrue mostly from lawsuits in that country. Public discussions about tobacco lawsuits, which educate the public about smoking caused addiction and disease, happen most frequently and intensively when the lawsuit is local. A news story about a large American verdict, on the other hand, is more likely to be the occasion for wonder than for intense debate in another country. Furthermore, cigarette price increases to cover litigation and settlement costs will not occur in a country unless the industry's cost structure in that country has been directly affected. Nor is there much chance that funds collected from health care reimbursement cases in one country will be spent on tobacco control in another country.

The international character of the tobacco industry gives it strength but also vulnerability. Admissions on the Philip Morris USA website that smoking is addictive and causes disease, designed to deal with US litigation and public relations needs, cannot be disavowed anywhere Philip Morris products are sold. Lawsuits and other tobacco control activities can now build on premises that would have been vigorously contested in the recent past. Similarly, the documents obtained in the American cases are typically relevant everywhere these companies do business. Furthermore, evidence of industry misconduct developed in one country in a region may be particularly applicable to other countries in that region.

\section{. provisions protecting the rights of children might be used to limit the distribution of cigarettes by and to minors}

Finally, the movement by NGOs to use public interest litigation to achieve tobacco control goals is just beginning. For example, the current precedents applying legal and constitutional provisions to limit tobacco advertising and smoking in public places can be invoked in many more countries, and provisions protecting the rights of children might be used to limit the distribution of cigarettes by and to minors.

\section{CONCLUSION}

The cheering is justified. Litigation has achieved benefits for tobacco control that were simply not obtainable otherwise. So long as the threat of litigation remains viable, tobacco companies may be deterred from pursuing outrageous schemes that do not violate specific laws or regulations. More areas of past industry misconduct remain to be explored and exposed. And the benefits for tobacco control outside the USA have only just begun.

Tobacco Control 2003;12:1-2

Correspondence to: Professor Richard Daynard, Tobacco Products Liability Project, Northeastern University School of Law, 400 Huntington Avenue, Boston, MA 02115, USA;

rdaynard@lynx.neu.edu

\section{REFERENCES}

1 Broder J. California jury allots damages of $\$ 28$ billion to ill smoker. New York Times 2002;5 October:A14.

2 Faircloth G. Judge cuts Philip Morris penalty to $\$ 28$ million. Wall Street Journal 2002; 19 December:D4.

3 Simon II Litigation, 2002 U.S. Dist. LEXIS 19773, U.S. District Court E.D. N.Y., 15 October 2002.

4 Daynard R, Bloch M, Roemer R. A year of living dangerously: the tobacco control community meets the global settlement. Public Health Rep 1998;1 13:488-97.

5 Pertschuk M. Smoke in their eyes: lessons in movement leadership from the tobacco wars. Vanderbilt University Press, 2001.

6 Bialous SA, Shatenstein S. Profits over people: tobacco industry activities to market cigarettes and undermine public health in Latin America and the Caribbean. Pan American Health Organization, 2002. URL: http://www.paho.org/English/HPP/HPM/ TOH/profits_over_people.htm

7 Philip Morris USA. Health issues. URL: http://www.philipmorrisusa.com/ health_issues/default.asp

8 Philip Morris USA. Low tar cigarettes. URL http://www.philipmorrisusa.com/ health_issues/low_tar_cigarettes/onsert.asp

9 Johnston LD, O'Mallay PM, Bachman JG. Teen smoking declines sharply in 2002, more than offsetting large increases in the early 1990s. Anne Arbor: University of Michigan News and Information Services. URL: www. monitoringthefuture.org

10 Nannozi T. Judge orders for anti-smoking law, The Monitor 2002; 12 December 2002, viewed at: http://allafrica.com/stories/ 200212120552.html on 21 December 2002

11 Tahin MA. Legal victory in Bangladesh, Release of 2 December 2002 by Work for a Better Bangladesh.

12 Philip Morris Companies Inc, form 10-Q, third quarter 2002, filed with the Securities and Exchange Commission.

13 Francey N, Chapman S. "Operation Berkshire": the international tobacco companies' conspiracy. BM 2000;321:371-4. 